\title{
Educating Radiologists for Self-governance
}

\author{
Richard B. Gunderman, MD, PhD, Paul J. Martin, BA
}

Key Words: Self-governance; autonomy; Ostrom; radiology; radiologists.

For radiology practices to thrive, radiologists need to expand their intellectual and professional horizons beyond the boundaries of radiology. Detection and analysis of lesions, formulation of differential diagnosis, making recommendations for further evaluation, and performing diagnostic and therapeutic procedures are the core of radiology practice, but if those doing the work do not learn to see the larger sociological, economic, political, and philosophical contexts in which they work, they will likely play little role in governing themselves, instead coming to resemble passengers on a professional bus whose course they do not control or even understand.

One of the American scholars who did the most over the past 50 years to illuminate the larger contexts of professional life, and in particular the conditions for professional self-governance, was Elinor Ostrom, the only woman and the first noneconomist to receive the Nobel Prize in economics (1). Although she was not a radiologist, her groundbreaking work provides deep insights into the governance of radiology as a profession. Because she is unknown to most radiologists, we begin with a summary of her life and work, followed by a synopsis of her writings on the conditions of self-governance and the timely insights they provide to radiologists who aspire to play a role in charting their own course.

\section{Life and Work}

Born in Los Angeles in 1933, Ostrom was the only child of a musician and a set designer (2). Her parents divorced when she was young, and she grew up in Beverly Hills under straitened circumstances. After graduating from Beverly Hills High School, she attended University of California, Los Angeles, from which she graduated with honors with a degree in political science in only 3 years. She married a

This is the author's manuscript of the article published in final edited form as:

Gunderman, R. B., \& Martin, P. J. (2018). Educating Radiologists for Self-governance. Academic Radiology, 25(4), 540-542. https://doi.org/10.1016/j.acra.2017.12.017 
classmate, whom she helped to put through Harvard Law School. After their divorce, she applied to the PhD program at University of California, Los Angeles, in economics, but was rejected, so she switched to political science. There, she met her second husband, Vincent Ostrom, whom she married in 1963, and received her $\mathrm{PhD}$ in 1965.

Ostrom accompanied Vincent to Indiana University, where he had accepted a position in political science that same year. Several years later, she began staffing an inconveniently timed 7:30 am American government class that no faculty members wanted to teach, and soon she gained a permanent faculty position. In 1973, she and Vincent founded the Workshop in Political Theory and Policy Analysis, which they ran for 39 years. Over the years, she published many papers and books in the fields of political science, management and administration, and organizational theory. Some of her special interests were the management of common resources and polycentric models of governance.

Among the important empirical investigations she helped to conduct were studies of consolidation among municipal police departments and school districts. Of course, consolidation of medical practices, hospitals, and health systems is an important theme in contemporary radiology. Ostrom found that among police departments, small- and medium-sized departments generally outperformed larger ones in terms of rates of victimization, police response times, citizens' readiness to call police, and relationships between police and community members (3). Likewise, multiple small school districts generally outperformed one large one (4).

Before Ostrom's work, many political scientists and public administrators had assumed that average citizens were too uneducated, inexperienced, and preoccupied by other concerns to govern themselves effectively. What they needed were experts with masters and doctoral degrees in business and social science fields to chart the appropriate course for them. Elinor and Vincent Ostrom found, however, that many supposedly intractable problems-including how to protect and sustain communal resources such as the natural environment—could be solved quite successfully by ordinary community members operating at the local level. 
Similar principles apply to radiology. Radiology groups do not necessarily need to be run by hospital or health system administrators, radiologists who have stepped away from clinical work to devote their efforts full time to management, or businesspeople. Groups of radiologists can in fact govern themselves and thrive by doing so, benefitting more from their mutual knowledge and respect and shared commitment than they could from external managerial expertise. If they are to succeed, however, they need to understand the conditions of successful self-governance. Ostrom identifies eight such conditions.

\section{Eight Conditions of Self-governance}

Ostrom argued that for communities—including groups of radiologists— to govern themselves, eight conditions need to be satisfied (5). First, they need to be part of a coherent group. Of course, the vast majority of radiologists are part of a group, whether a physician-owned radiology practice, a multispecialty practice, or an employed arrangement with a hospital or health system. But Ostrom means more than this. Radiologists need not only be part of a group but also part of a group that stands for something - a group with a specific mission or purpose, such as excellence in patient care. Radiologists who do not know what they stand for cannot succeed at self-governance.

Second, the members of the group must actually earn benefits by investing their time, energy, and expertise in the group. This highlights a huge problem with publicly traded radiology groups, whose owners may view a physician group as just another opportunity to make money and who have no experience or personal investment in the care its members provide. This also highlights a large pitfall in consolidation, namely, organizations can grow so large that members can no longer see the contributions that other members are making. Such a lack of mutual understanding can sow the seeds of ignorance and distrust, causing groups to disintegrate.

Third, the members of a group must agree on decisions, attempting to avoid situations where some tell others what they must do. Again, this highlights an important problem for radiology groups that are owned or controlled by nonradiologists, or at least nonphysicians. When members believe that they 
are subject to the authority of someone who does not engage in or even understand the work they do, they are much likelier to feel that they are being exploited. For self-governance to work well, everyone doing the work needs to have a voice in how, when, where, by whom, and why the work is being done. Only then will colleagues feel fully engaged in their profession.

Fourth, when selfish or disruptive conduct emerges, the group itself must have the ability to detect and discipline those responsible. This means that the group takes responsibility for policing itself, rather than expecting someone else to do the job for it. Whenever a potentially self-governing group looks outside its own members to carry out such functions, it effectively cedes governance to another person or organization. Without doubt, handling such situations can be one of the most difficult challenges groups face, but it is a challenge to which they must rise if they are to exercise responsibility for charting their own professional course.

Fifth and sixth, when conflicts arise, groups move swiftly to resolve them in a transparent and proportionate fashion. Although one sign of a thriving group is a relative paucity of conflict, in diverse organizations honest disagreements should arise from time to time, and how groups respond to such tensions is more important than preventing them from arising in the first place. This means acknowledging them when they arise, making sure all parties to a conflict know that their voices have been heard, and adopting a method of resolution that the parties can agree is just, even if all are not satisfied with the outcome.

Seventh, group members need sufficient latitude to manage their own affairs. This means that no one-inside or outside the group—is micromanaging them. To forfeit the capacity for self-governance is to start down a path toward de-professionalization, from which recovery can prove very difficult. But when group members know and trust one another, many decisions can be made at an individual level, without a great deal of oversight or interference. The need for an external overseer implies that the organization can no longer manage its affairs in a mutually trustful and respectful fashion, reflecting the erosion of self-governance's foundation. 
Eighth, even large self-governing organizations operate by principles they would use if they were smaller, including reliance on collegial relationships and mutual respect. When organizations grow so large or so dispersed that group members no longer have any hope of knowing one another, they begin to adopt bureaucratic patterns of management that undermine reliance on personal relationships and the mutual knowledge and respect to which they can give rise. For example, a radiology practice that is so widely geographically dispersed that many of its members have never even met each other has little prospect of governing itself effectively.

\section{Excellence in Self-governance}

Self-governing radiology practices are likely to enjoy higher levels of radiologist engagement than those that are externally controlled. But for self-governance to thrive, radiologists must know and respect each other and their shared mission well. Where such mutual understanding is missing, many practices begin relying more and more on techniques of control, such as increasingly complex systems of incentives and disincentives, in an effort to compel radiologists to do things they would not choose to do on their own. Such manipulation both reflects and exacerbates a decline in professionalism and further undermines opportunities for self-governance.

Elinor Ostrom envisioned another possibility, which she described in these terms: "We are neither trapped in inexorable tragedies nor free of moral responsibility for creating and sustaining incentives that facilitate our achievement of mutually productive outcomes.” (6) In other words, radiologists have in themselves—individually and collectively—-the means for overcoming the many challenges and crises that face them. But if they are to rise to such challenges, they must educate themselves and each other —at every phase of their professional training and work — to function as informed, free, and responsible colleagues. 


\section{References}

1. Nobelprize.org. Elinor Ostrom—biographical. Available at:

https://www.nobelprize.org/nobel_prizes/economic-sciences/laureates/2009/ostrom-bio.html. Accessed December 1, 2017.

2. Tarko V. Elinor Ostrom: an intellectual biography. London: Rowan and Littlefield, 2016.

3. Ostrom E, Parks RB, Whitaker GP, et al. The public services production process: a framework for analyzing police services. Policy Studies J 1978; 7:381-389.

4. Ostrom V, Ostrom E. Public choice: a different approach to the study of public administration. Public Administration Rev 1971; 31:203-216.

5. Ostrom E. Governing the commons: the evolution of institutions for collective action. Cambridge: Cambridge University Press, 1990.

6. Ostrom E. A behavioral approach to the rational choice theory of collective action. Am Polit Sci Rev 1998; 92:1-22. 